\title{
The dry summer on the Upper Nile
}

\author{
A. D. Milne M.B., C.M.
}

To cite this article: A. D. Milne M.B., C.M. (1900) The dry summer on the Upper Nile, Scottish Geographical Magazine, 16:2, 89-92, DOI: 10.1080/00369220008733129

To link to this article: http://dx.doi.org/10.1080/00369220008733129

曲 Published online: 27 Feb 2008.

Submit your article to this journal $2 \pi$

Џll Article views: 2

Q View related articles ๘ 
are hardly worth counting as occupation. The Vipsya is entirely without people, and in the far west, until the traveller has descended a long distance into the Loangwa valley, he rarely encounters: more than two or three villages on a day's march. The great centres of population are Bandawe among the Tonga tribe, Ekwendeni and Hora among the Ngoni and Tumbuka tribes, Kondowi among the mixed Henga and Poka, and Karonga among the mixed Henga and Konde. No exact census has yet been made.

\section{THE DRY SUMMER ON THE UPPER NILE.}

$$
\text { By A. D. Milne, M.B., C.M. }
$$

IN the month of August, 1871, Baker Pasha wrote as follows ${ }^{1}$ :- "All my anticipations of successful cultivation had been fruitless. The drought of this year had caused a general scarcity. The months of July and August should have the heaviest rainfall; July had just expired with a rainfall of only 1.13 inch. ..."

This year, 1899, some 20 miles south of Gondokoro, Baker Pasha's station, twenty-eight years after the above was penned, one might almost write in identical terms of the weather and "general scarcity." This July has just expired with a rainfall of $2 \cdot 61$ inches.

On our first arrival here in the latter part of January, the first aim was to run up suitable habitations for the men; and many were the inquiries directed towards ascertaining the duration of the dry weather. Both by the soldiers themselves-most of them natives of the various tribes here and near here-and by the native dwellers in the islands, the dry weather was announced as beginning in the latter part of November and continuing on to March. In April the rain would begin "little little "-one or two days' rain and cloud, four or five days' sunshine, the latter gradually diminishing, till by June or July at latest the floods would be in full force. April arrived with weather as pronised; and great was. the anxiety over the possible ruin of batches of sun-baked bricks. May followed much the same as April, but with one week of heavy rain. Finally, with much rejoicing, the last brick of the season was laid; and the rain was looked for with as much eagerness as work had before been hurried and scamped for fear of it. But as June and July came and passed with a scantier and scantier rainfall, it became at last impossible to ignore the probability that this season was going to be a year of lean cattle. In May, after the heavy rainstorms, crops had been hastily put into the ground. Now, instead of dhurra-fields waving ten-foot high, the stalks are not much above the height of one's knee or waist, while the heads are all shrivelled and wizened. Some fields of Lubia (beans) have had to be rooted up, being scorched by the sun. The scrub bush of the jungle wears the indescribable browned and withered appearance due to excessive heat. 
It must be remembered that I am speaking more particularly of the country immediately to the south of Gebel Regaf; and that though the conditions seem more or less general elsewhere, in certain favoured localities they are exceptional. Thus, at a village some. 36 miles to the south, on a range of hills near the east bank of the Nile, are some 150 to 200 acres of crops well forward and rapidly ripening. Its inhabitants complain of no lack of rain. And away to the east, beneath the shadow of the Bellinian and Illyrian hills, crops are plentiful, I believe.

Of adverse signs the most important is the actual rainfall for this locality and the lowness of the Nile. The river has been steadily falling much below the anticipated lowest point of April, when levels were first recorded. The charts speak for themselves.

Other indications of a scarcity I noticed on a journey to Afuddo, the next station to this, 100 miles away. There I found a colony of thirty Madis, who had come across from the west bank of the Nile to the then more prosperous other side, as, owing to the lack of rain, their own crops had failed. On the way back to Fort Berkeley I passed through a village, and found all its inhabitants sittirg disconsolately round their Lares and Penates. Asking what was the matter, I learned that the inhabitants of a neighbouring friendly (?) village on their way to buy corn in the Shuli country, 60 or 70 miles distant, had helped themselves in passing to the little stock of grain left. A woebegone woman sitting near by graphically filled her mouth with dirt as evidence of all she had to eat. Further on, a husband, wife, and child leading a goat were passed, the latter to be bartered for corn in the favoured Shuli country. At another village, where on the road down I had shot a couple of antelope, the Sheikh came up and greeted me with an excess of friendliness, and said he had sent some of his men out into the bush to see where the game was. This rather took me aback, as the Baris are not a sporting race, and I asked why. "Oh," he said, "all my men are at Dufileh buying food; and I," smiling and patting his stomach, "am very hungry."

- Of course a certain allowance must be made for the improvidence of the native, who is not unlikely to be occasionally hard up for food at the end of the dry weather. Still, straws show how the wind blows, and judged from personal observation here and elsewhere, the scarcity is too general not to be severely felt.

The state of the Nile, and also of the Khor Asua and the Khor Atabbi and other big rivers flowing into the Nile between this and Afuddo, affords a pretty good indication that even in the mountainous regions to the east, and in the whole of the Great Lake basins, the rainfall must be small and considerably less than usual. For I take it that a permanent rise in the Nile waters here must depend chiefly on a, rise in the level of one or both lakes, the big tributary rivers being responsible for the oscillations. For example, the rise recorded at Fort Berkeley on May 16 th originated in a very heavy rain on the night of the 14 th and several succeeding days of rain occurring in the Shuli country, 120 miles to the south-east. Through these lands run the 
Khor Asua, the Atabbi, etc. Lieut. Gage, 7th Dragoon Guards, experienced these showers on his way to Mella, a village about 45 miles up the Khor Asua, and 120 miles from here. If the Wadelai diagram for May be studied, it will be seen that there is no phenomenal rise recorded for the 13th May, which would allow of a flood traversing the 200 odd miles and more of waterway, at the rate of 3 miles an hour, reaching Fort Berkeley on the 16th. In spite of the above-mentioned heavy rains, six weeks later these rivers were all clear streams, at the most knee-deep. The Khor Asua certainly deserves all that Baker Pasha says of it, and in full flood must take some negotiating to get across. A boat has been placed at the junction of it and the Atabbi, and it will be. interesting to see how it works.

The Nilometer consists of a pole firmly fixed in a mudbank, and marked in feet and inches. Five foot has been taken as an arbitrary level to work from till experience shows which is the best (i.e. the lowest) starting-point. - Levels are noted every day at 5 P.M.

The rain-gauge consists of a zinc funnel three inches in diameter, bound together with copper rivets. It was skilfully made for me by Armourer-Sergeant Stong out of zinc packing and copper (trade) wire. I am indebted to Major Tickell, D.S.O., 14th Hussars, for the equation for working out results. The accessories consist of a pickle bottle as receiver, placed in an open space inside the fort, well away from buildings or trees. The funnel is fitted into a cork to avoid outside drippings reaching the interior. The rim of the gauge is 12 inches above ground. Readings are nominally taken every morning at 9 A.M., but with slight rain as soon as the showers are over. The water is measured in a minim measure.

Through the courtesy of Lieut. Cope, R.A., I have obtained two diagrams of the Nile level at Wadelai for the months of May and June. Unfortunately there is no datum level drawn on them.

\section{RAINFALL.}

Fort Berkeley, Equatorial Provinces.

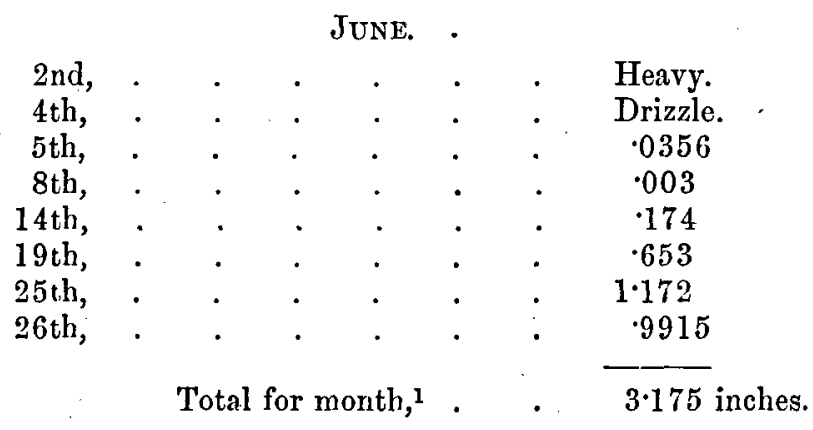




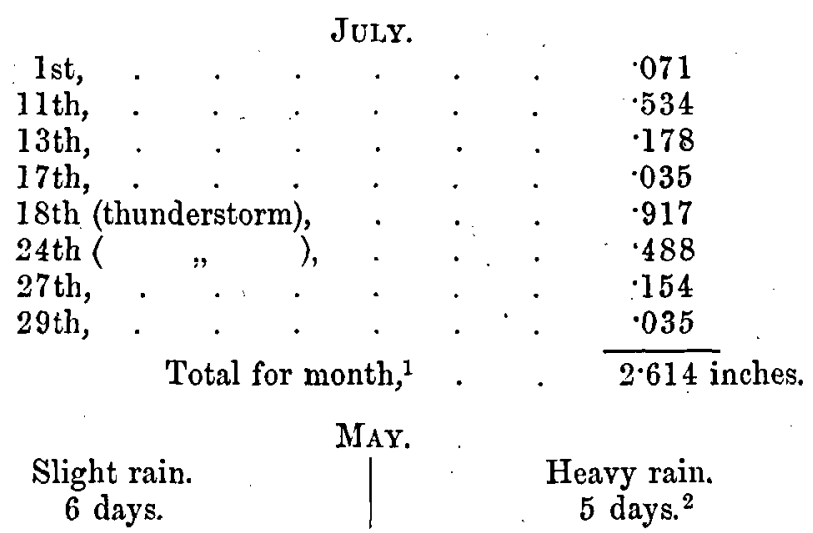

\section{RHODESIA.}

\section{Report on the Administration of Rhodesia. The British South Africa Company. ${ }^{3}$}

Impressions of South Africa. James Bryce.

THAT vast country which lies between the German and Portuguese South African possessions, and extends from Lake Tanganyika southward to the Transvaal, must at present be an object of peculiar interest to us, as it will certainly soon be one of the most important fields for British enterprise and statesmanship. Within the present year, it may be hoped and indeed expected, there will arise new facilities for the development, and new problems for the administration, of a land which is eminently fitted to become the home of a permanent and self-supporting colony. When the sources of the old unrest and insecurity shall have been done away, when political and fiscal boundaries which correspond in no respect either to racial differences or to physical divisions shall have disappeared, the normal growth of British South Africa, in population and industry, will reveal more fully what are the resources and what is to be the future of the great plateau. In the meantime it is worth our while to take notice of what has been done and of what has been discovered in those parts which are at once the most remote, the least developed, yet, in the opinion of many, not the least valuable of our South African possessions.

The Report of the British South Africa Company gives very strik-

1 We hope to publish a diagram showing the fluctuations of the Nile, when it can be drawn for twelve months. - En.

2 On May 6th there was a heavy thunderstorm in the night, accompanied by an earthquake. It is interesting to note in this connection that Gebel Regaf means " the trembling hill." Natives are well aware of its peculiarities.

${ }^{3}$ We are indebted to the British South Africa Company for permission to use the accompanying illustrations and maps. 